\title{
PENGISI DAYA BATERAI TELEPON SELULER PORTABEL BERBASIS PANEL SURYA
}

\author{
Ketut Udy Ariawan'1) \\ ${ }^{1}$ Fakultas Teknik dan Kejuruan, Universitas Pendidikan Ganesha \\ Email: udyariawan@undiksha.ac.id
}

\begin{abstract}
ABSTRAK
Panel surya atau sering disebut solar cell merupakan suatu alat atau komponen yang terdiri dari sel surya yang mampu mengubah cahaya matahari menjadi energi listrik. Panel surya ini dapat dimanfaatkan sebagai pembangkit listrik mini, salah satunya sebagai pengisi daya baterai telepon seluler yang dapat digunakan dimana saja dan kapan saja. Panel surya yang digunakan memiliki spesifikasi tegangan 5 Volt, daya 1.2 Watt, arus $240 \mathrm{~mA}$, dan memiliki dimensi ukuran $11 \times 7 \mathrm{~cm}$. Buck boost step down converter yang digunakan memiliki spesifikasi tegangan input 5-32 Volt, tegangan output 1.2-35 Volt, dan menggunakan chip XL6009. Rangkaian modul pengisi daya baterai yang digunakan seri TP4056 Li-ion dengan spesifikasi tegangan input 4.5-5.5 Volt. Rangkaian modul USB yang digunakan memiliki spesifikasi tegangan input 6-40 Volt, dan tegangan output 5 Volt. Pada pengisi daya baterai telepon seluler portabel ini, sinar matahari mendorong panel surya mengeluarkan tegangan untuk mengisi sebuah baterai yang bertujuan menyimpan tegangan dari panel surya. Output dari panel surya maksimal 5 VDC dan output dari baterai maksimal 3.7 VDC dengan menggunakan buckboost converter, output dari rangkaian menjadi 5 VDC. Intensitas cahaya matahari sangat mempengaruhi output tegangan panel surya. Intensitas cahaya matahari terbesar terjadi pada pukul 12.00 Wita, dengan rata-rata intensitas cahaya yang diperoleh sebesar 63.000 Candela menghasilkan tegangan sebesar \pm 5.3 Volt dan arus sebesar \pm 0.06 Ampere. Pada hasil pengujian yang telah dilakukan, diperoleh waktu pengisian daya baterai telepon seluler selama 2 jam 10 menit. Kapasitas baterai pengisi daya berada pada level 1 strip, yang mampu mengisi kapasitas baterai telepon seluler hingga $29 \%$.
\end{abstract}

Kata kunci: panel surya, buckboost converter, pengisi daya, baterai

\begin{abstract}
Solar panels or often called solar cells is a device or component that consists of solar cells that are able to convert sunlight into electrical energy. This solar panel can be used as a mini power plant, one of which is a cell phone battery charger that can be used anywhere and anytime. The solar panel used has a voltage specification of 5 volts, 1.2 Watt power, $240 \mathrm{~mA}$ current, and has dimensions of $11 \times 7 \mathrm{~cm}$. The buck boost step down converter used has a 5-32 Volt input voltage specification, an output voltage of 1.2-35 Volts, and uses an XL6009 chip. The battery charger module series used in the TP4056 Li-ion series with 4.5-5.5 Volt input voltage specifications. The USB module circuit used has a 6-40 Volt input voltage specification, and a 5 Volt output voltage. In this portable cell phone battery charger, sunlight pushes the solar cell to release a voltage to charge a battery that aims to store the voltage from the solar cell. The maximum output of the solar cell is 5 VDC and the output of the battery is a maximum of 3.7 VDC using a buckboost converter, the output of the circuit becomes 5 VDC. The intensity of sunlight greatly affects the solar cell voltage output. The greatest intensity of sunlight occurred at 12.00 West Indonesia Time, with an average light intensity of 63,000 Candela resulting in a voltage of \pm 5.3 Volts and a current of \pm 0.06 Ampere. From the results of the tests that have been carried out, obtained the charging time of the cell phone battery, which is 2 hours 10 minutes. The capacity of the battery charger is at level 1 strip, which is able to charge the cell phone battery up to $29 \%$.
\end{abstract}

Keywords : solar cell, buckboost converter, charger, battery 


\section{PENDAHULUAN}

Panel surya merupakan suatu alat yang terdiri dari sel surya untuk mengubah cahaya matahari menjadi listrik. Panel surya disebut juga sel photovoltaic, photovoltaic dapat diartikan sebagai "cahaya-listrik". Panel surya terdiri dari 3 lapisan, yaitu lapisan panel tipe P di bagian atas, lapisan pembatas di tengah, dan lapisan panel tipe $\mathrm{N}$ di bagian bawah. Akibat efek fotoelektrik maka sinar matahari menyebabkan terjadinya pelepasan elektron pada lapisan panel tipe $P$, sehingga hal ini mengakibatkan muatan proton mengalir menuju lapisan panel tipe N. Dengan demikian, terjadi proses perpindahan arus proton sebagai arus listrik [6].

Berdasarkan catatan sejarah, teknologi panel surya atau solar cell bahkan sudah ada di abad ke-18, tepatnya pada tahun 1839 seorang ahli fisika asal Perancis bernama Alexandre Edmund Becquerel pertama kali mencetuskan teknologi panel surya. Awalnya teknologi panel surya pertama kali dicetuskan oleh beliau melalui percobaan penyinaran dua elektroda menggunakan berbagai spektrum cahaya yang menghasilkan efek photovoltaic. Photovoltaic (photo = cahaya dan voltaic = tegangan listrik) merupakan proses pembentukan energi listrik dari energi cahaya. Namun, pada saat itu jumlah energi listrik yang dihasilkan terlalu sedikit dan mudah habis. Pada tahun 1904, Albert Einstein pernah meneliti mengenai panel surya dan beliau menamakan percobaan tersebut dengan nama efek fotolistrik. Barulah di tahun 1941, peneliti bernama Russel Ohl berhasil mengembangkan teknologi panel surya sekaligus mematenkan produknya tersebut. Beliau dikenal sebagai orang pertama yang menemukan teknologi panel surya dan penggunaan panel surya buatannya masih digunakan sampai sekarang [4].

Pada tahun 2000, aplikasi panel surya telah diterima secara luas. Banyak pabrik yang memiliki kapasitas produksi hingga ribuan mega watt per tahunnya. Indonesia, bahkan juga turut ikut serta dalam mensuplai kebutuhan energi surya secara global [4]. Panel surya pada masa kini tidak hanya bersifat statis, akan tetapi juga dapat bergerak mengikuti pergerakan arah sinar matahari atau bersifat cerdas dan murah. Pengembangan solar tracker cerdas ini sangat banyak di kembangkan sebagai penelitian. Pada hasil penelitian yang telah dilakukan oleh I Wayan Sutaya dan Ketut Udy Ariawan, diperoleh persentase penghematan konsumsi daya pada solar tracker cerdas dengan yang tidak cerdas adalah sebesar $85 \%$ [7].

Telepon genggam atau telepon seluler atau sering disebut handphone $(\mathrm{Hp})$ merupakan salah satu media komunikasi yang praktis, karena mudah dibawa dan dapat digunakan dimana saja. Terkadang orang-orang sering kesal ketika telepon selulernya tersebut mati dikarenakan baterainya habis. Apalagi pada saat berpergian, dimana tidak memungkinkan untuk mengisi daya baterai dengan menggunakan charger. Charger tersebut memerlukan tegangan 220 Volt agar dapat digunakan untuk mengisi daya baterai.

Saat ini, ada berbagai solusi alternatif untuk mengisi daya baterai telepon seluler dengan menggunakan tenaga listrik yang bersumber dari tenaga angin, tenaga air, bahkan dari baterai lain telepon seluler lain. Kebutuhan akan keberadaan energi listrik agar dapat mengisi daya telepon seluler tersebut sangat diharapkan oleh semua orang, dimana saja, dan kapan saja.

Dengan melihat permasalahan tersebut diatas, maka penulis merancang sebuah alat pengisi daya baterai telepon seluler portabel berbasis panel surya. Dengan adanya alat ini diharapkan masyarakat dapat melakukan pengisian daya baterai telepon selulernya dimana saja, dan kapan saja cukup dengan memaparkan panel surya dibawah sinar matahari saja.

\section{METODE}

Metode-metode yang digunakan dalam pengumpulan data penelitian ini dilakukan dengan cara sebagai berikut:

Metode kepustakaan, yaitu penulis mengambil referensi dari buku-buku dan internet yang berkaitan dengan teori yang akan dibahas. Metode pengujian, yaitu pada rangkaian pengisi daya agar output dari panel surya sebesar 5 Volt. Tegangan yang direncanakan pada panel surya maksimal 5 Volt dan 4,4 Volt pada rangkaian. Apabila tegangan yang direncanakan kurang dari ketentuan tersebut, maka akan dievaluasi ulang keseluruhan rangkaian agar sesuai dengan yang direncanakan.

Metode analisis data, yaitu dilakukan setelah pengujian pada rangkaian pengisi daya keseluruhan, rangkaian dikatakan berhasil apabila output pada rangkaian stabil sebesar 4,4 Volt dan tegangan dari panel surya minimal 4.8 Volt. Data-data yang diambil dalam pengumpulan data sebelumnya terdiri dari data hasil pengamatan dan pengukuran pada setiap perancangan, baik dari perancangan rangkaian maupun data-data tentang pengujian rangkaian pengisi daya. 
Pada perancangan dan pembuatan pengisi daya baterai telepon seluler portabel ini terdapat beberapa tahapan-tahapan yang harus diikuti agar dalam proses pembuatannya menjadi lancar dan tujuan dari penelitian dapat tercapai, yaitu dengan diagram alir (flowchart).

Tahap pertama adalah perancangan modul buck boost converter, metoda buck-boost tidak lain adalah kombinasi antara buck dan boost, dimana tegangan keluaran dapat diatur menjadi lebih tinggi atau lebih rendah dari tegangan masukan. Untuk dicatat dari buck-boost adalah bahwa tegangan keluaran memiliki tanda berlawanan dengan tegangan masukan. Oleh karena itu, metoda ini pun ditemui pada aplikasi yang memerlukan pembalikan tegangan (voltage inversion) tanpa transformer. Walaupun memiliki rangkaian sederhana, metoda buck-boost memiliki kekurangan seperti tidak adanya isolasi antara sisi masukan dan keluaran, dan juga tingkat ripple yang tinggi pada tegangan keluaran maupun arus keluaran [9].

Setelah perancangan modul buck boost converter, dilanjutkan dengan pengujian rangkaian buck boost converter menggunakan rangkaian charger portable. Buck boost converter diharapkan mampu menghasilkan output 5 Volt dengan input tegangan kurang atau lebih besar dari 5 Volt. Jika hal tersebut tercapai maka dilanjutkan dengan perancangan rangkaian modul charger baterai. Selanjutnya pengujian rangkaian modul charger TP4056, jika output mampu menghasilkan 5 Volt maka tahap selanjutnya dilanjutkan dengan perancangan rangkaian modul USB. Pada pengujian rangkaian modul USB, jika modul mampu menghasilkan output 5 Volt dengan input lebih dari 6 Volt dan kurang dari 40 Volt maka dilanjutkan dengan merancang rangkaian charger baterai portabel, kemudian memasang panel surya pada rangkaian charger baterai portabel. Charger baterai adalah suatu alat yang berfungsi untuk mengisi baterai dengan tegangan konstan hingga mencapai tegangan yang ditentukan. Bila level tegangan yang ditentukan itu telah tercapai, maka arus pengisian akan turun secara otomatis sesuai dengan setting dan menahan arus pengisian hingga menjadi lebih lambat [11].

Tahap selanjutnya, yaitu pengujian baterai charger dan panel surya pada rangkaian charger portabel. Apakah alat mampu mengisi baterai atau tidak, jika ya dilanjutkan dengan pengujian keseluruhan rangkaian dan analisa data. Setelah semua rangkaian bekerja sesuai dengan perencanaan dan charger portabel bekerja secara normal sesuai dengan yang diharapkan maka selanjutnya menuju proses tahap akhir, yaitu pembuatan laporan.

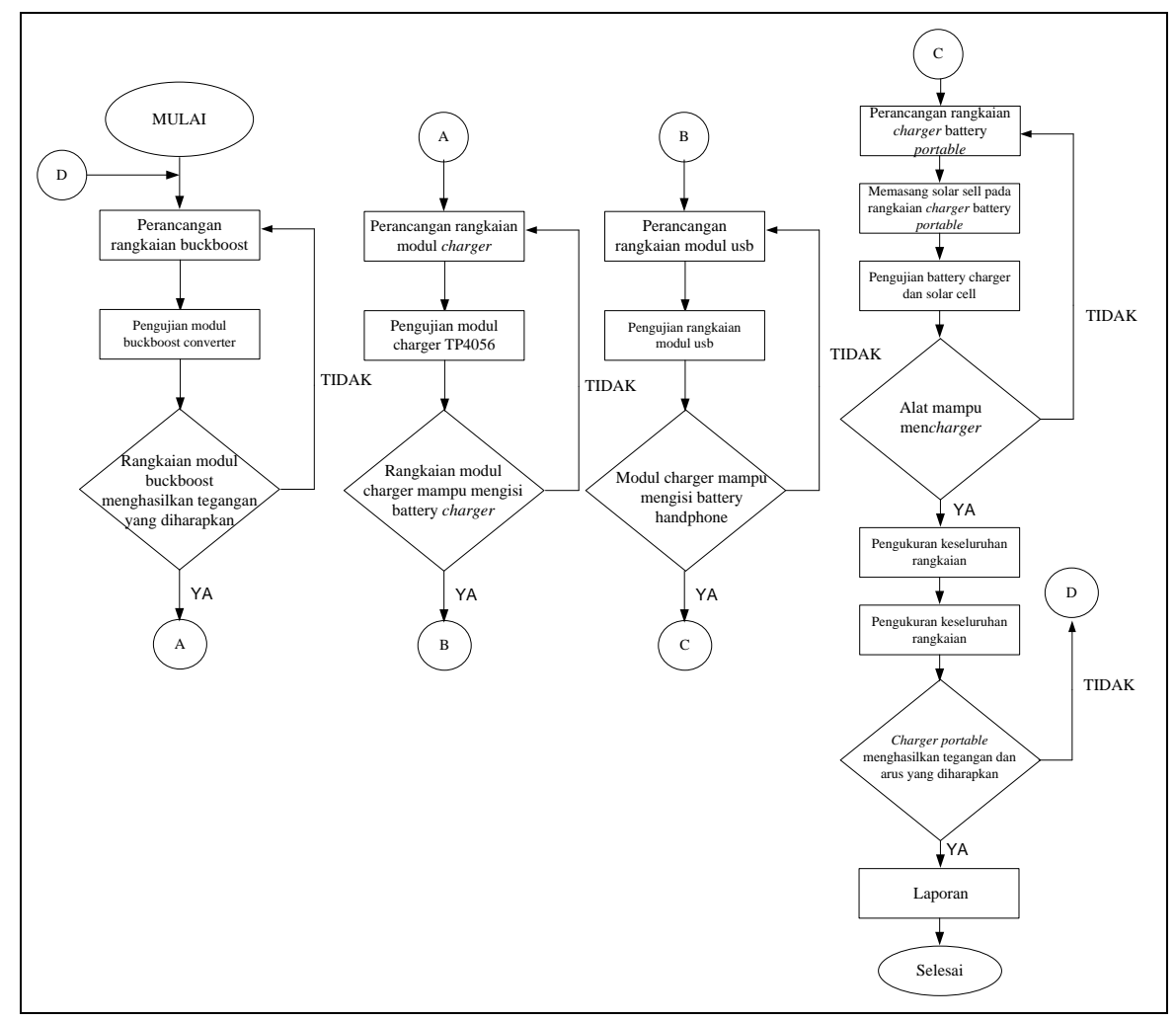

Gambar 1. Diagram Alir Perancangan dan Pembuatan Alat Pengisi Daya Baterai Telepon Seluler Portabel berbasis Panel Surya 
Sebelum dilakukan pembuatan alat pengisi daya baterai telepon seluler portabel berbasis panel surya yang sebenarnya, maka sebelumnya dilakukan perancangan blok diagram rangkaian keseluruhan sebagai berikut:

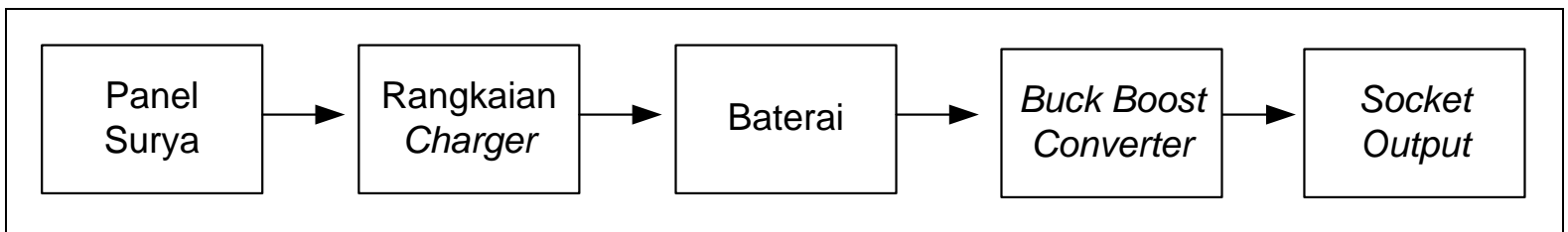

Gambar 2. Perancangan Blok Diagram Rangkaian Keseluruhan

Pada gambar diatas dapat dijelaskan bahwa tegangan dihasilkan dari panel surya masuk ke rangkaian charger, rangkaian charger menggunakan modul TP4056 Li-ion Charger Battery, kemudian tegangan akan mengisi daya baterai, daya baterai 3,8 Volt masuk ke buck boost converter mengeluarkan tegangan $\pm 5 \mathrm{~V}$ dan daya yang keluar melalui soket USB sebesar $0.11 \mathrm{~A}$.

Perancangan rangkaian pengisi daya terdiri dari buck boost converter, yang berfungsi sebagai penstabil tegangan yang dihasilkan oleh baterai, untuk dapat melakukan pengisian baterai telepon seluler dibutuhkan tegangan sebesar 5 Volt. Apabila output dari baterai kurang dari 5 Volt, maka output buck boost converter mengubah tegangan baterai dari sebelumnya 3,8 Volt menjadi 5 Volt.

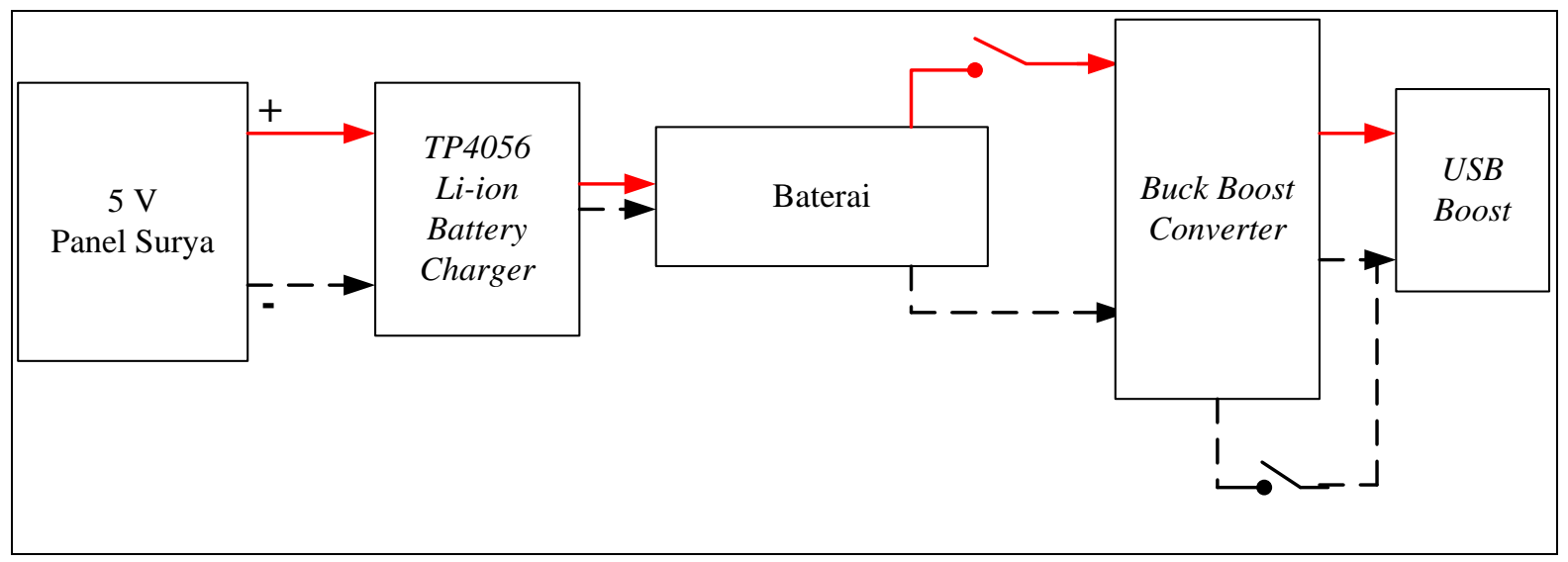

Gambar 3. Perancangan Blok Diagram Rangkaian Pengisi Daya

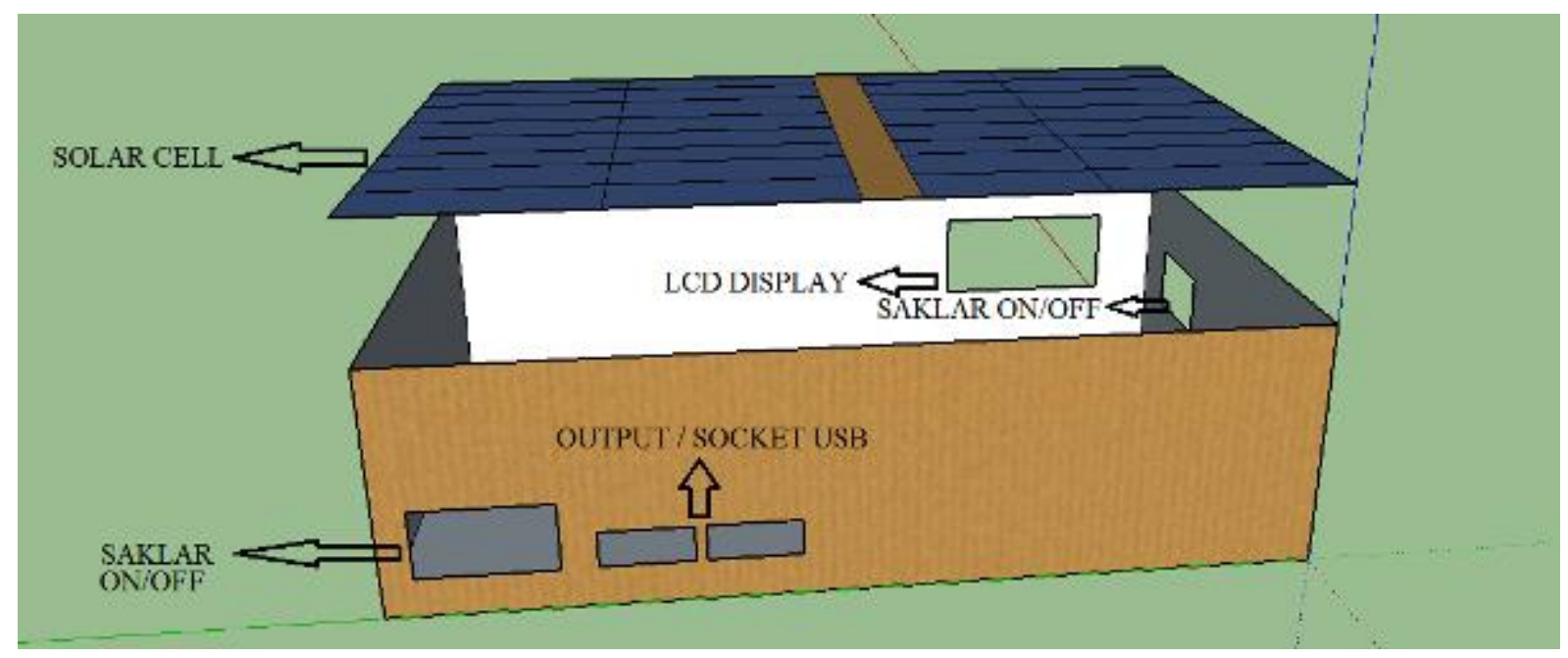

Gambar 4. Perancangan Desain Konstruksi Mekanik 


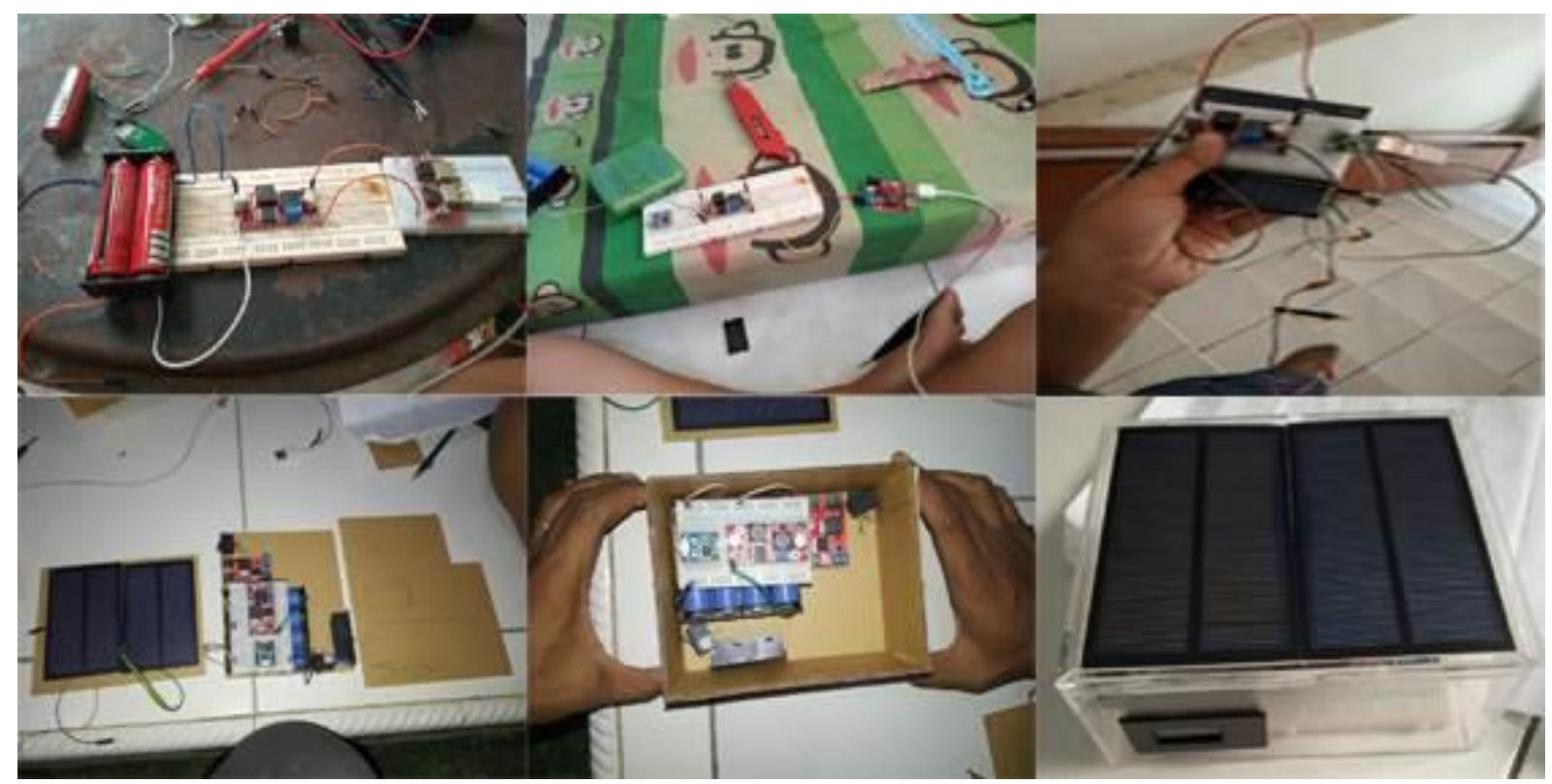

Gambar 5. Perancangan dan Pembuatan Rangkaian Keseluruhan

\section{HASIL DAN PEMBAHASAN}

Setelah dilakukan perancangan blok diagram, desain konstruksi mekanik, dan pembuatan rangkaian keseluruhan maka dihasilkan sebuah alat pengisi daya baterai telepon seluler portabel berbasis panel surya sebagai berikut:

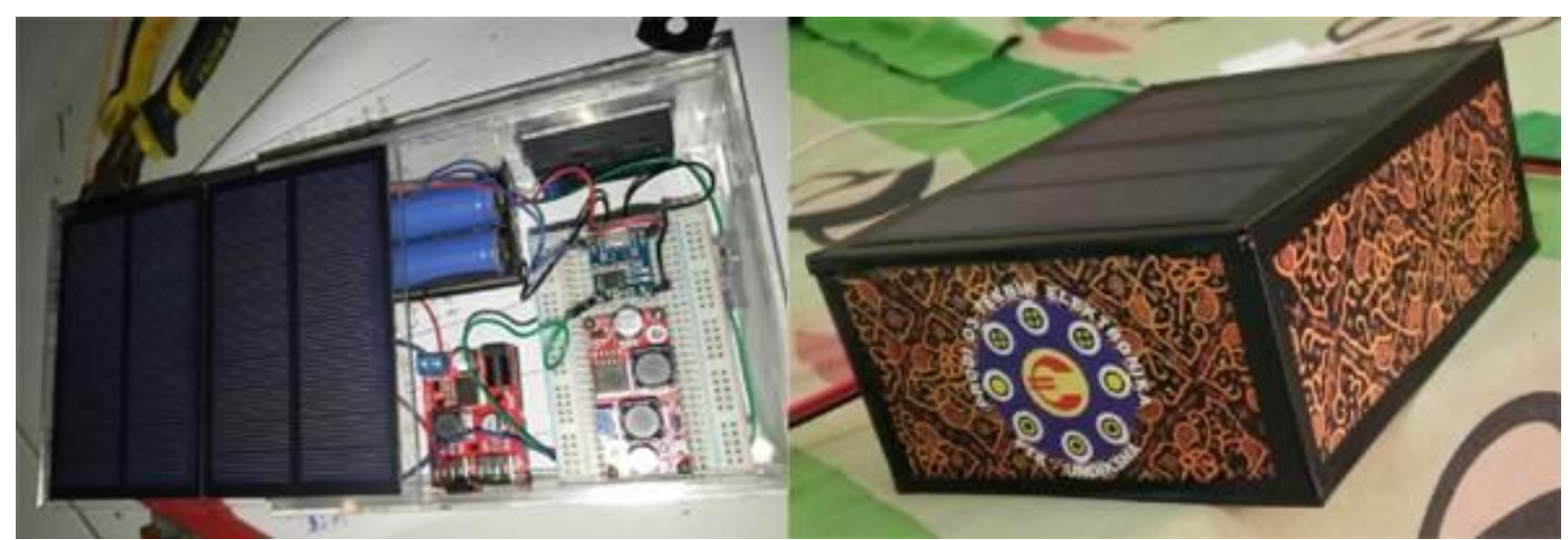

Gambar 6. Rangkaian Keseluruhan

Tahap selanjutnya, yaitu melakukan pengujian terhadap rangkaian keseluruhan yang telah dihasilkan. Pengujian ini dilaksanakan dalam dua tahap, dan dalam satu tahap terdapat 3 pengujian.

Tahap pertama dilakukan pengujian terhadap panel surya selama 3 hari berturut-turut, dengan kondisi cuaca yang kebetulan berbeda-beda. Waktu pelaksanaan pengujian ini dilakukan dari pukul 06.30 Wita - 18.00 Wita dengan selang waktu rata-rata pengambilan data sekitar 30-60 menit. Adapun yang diukur dalam pengujian ini adalah intensitas cahaya matahari yang diterima panel surya (menggunakan alat ukur flux meter), tegangan output dari panel surya dan buck boost converter (menggunakan alat ukur avometer), dan arus listrik (menggunakan alat ukur avometer).

Tahap kedua dilakukan pengujian waktu pengisian baterai telepon seluler dengan beban dan kapasitas berbeda. Beban yang digunakan berupa 3 buah baterai dengan tipe Li-ion $4.81 \mathrm{Wh}$, Li-Po 3000mAh, dan Li-Po 6000mAh. 


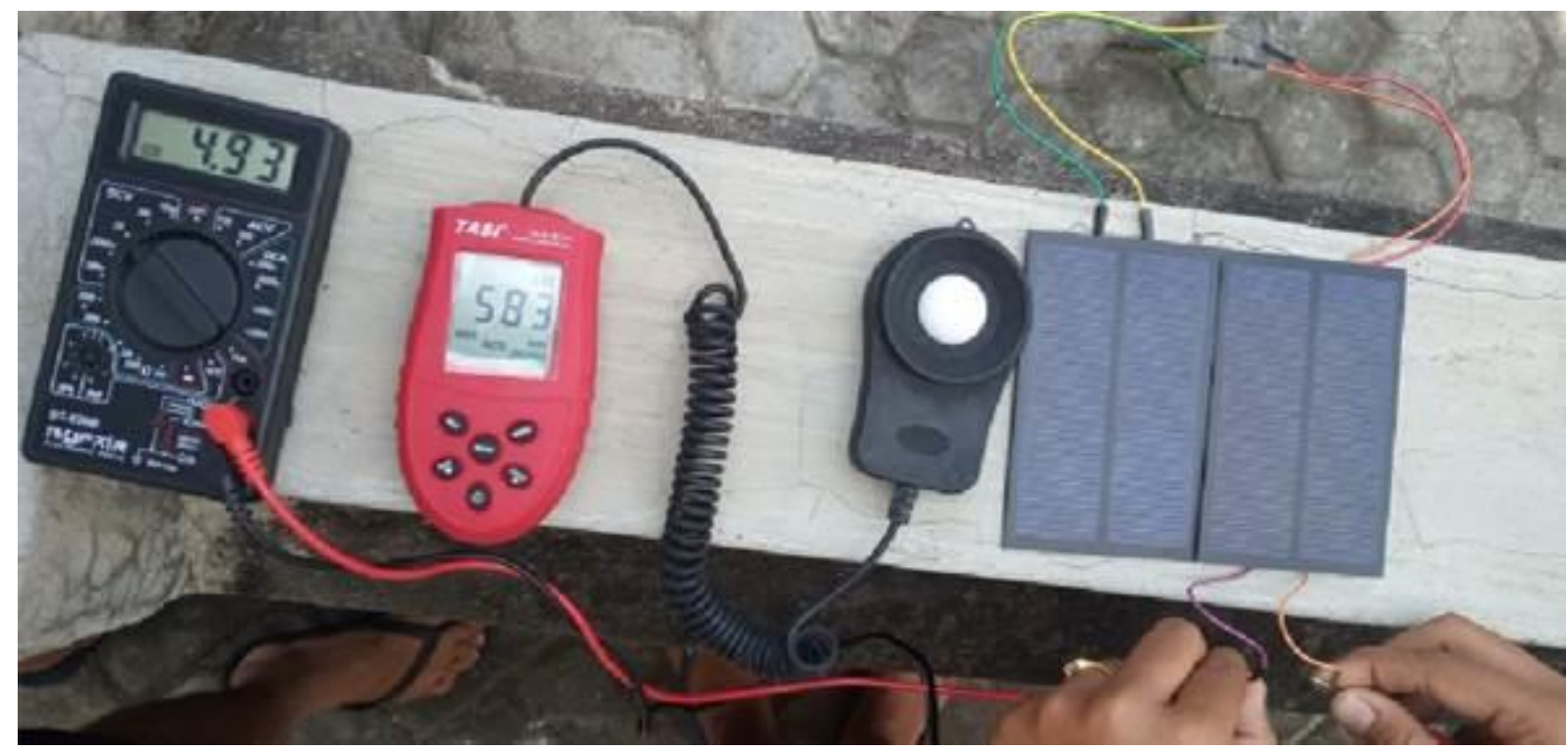

Gambar 7. Pengukuran Tegangan dan Arus Input dan Output yang dihasilkan Panel Surya

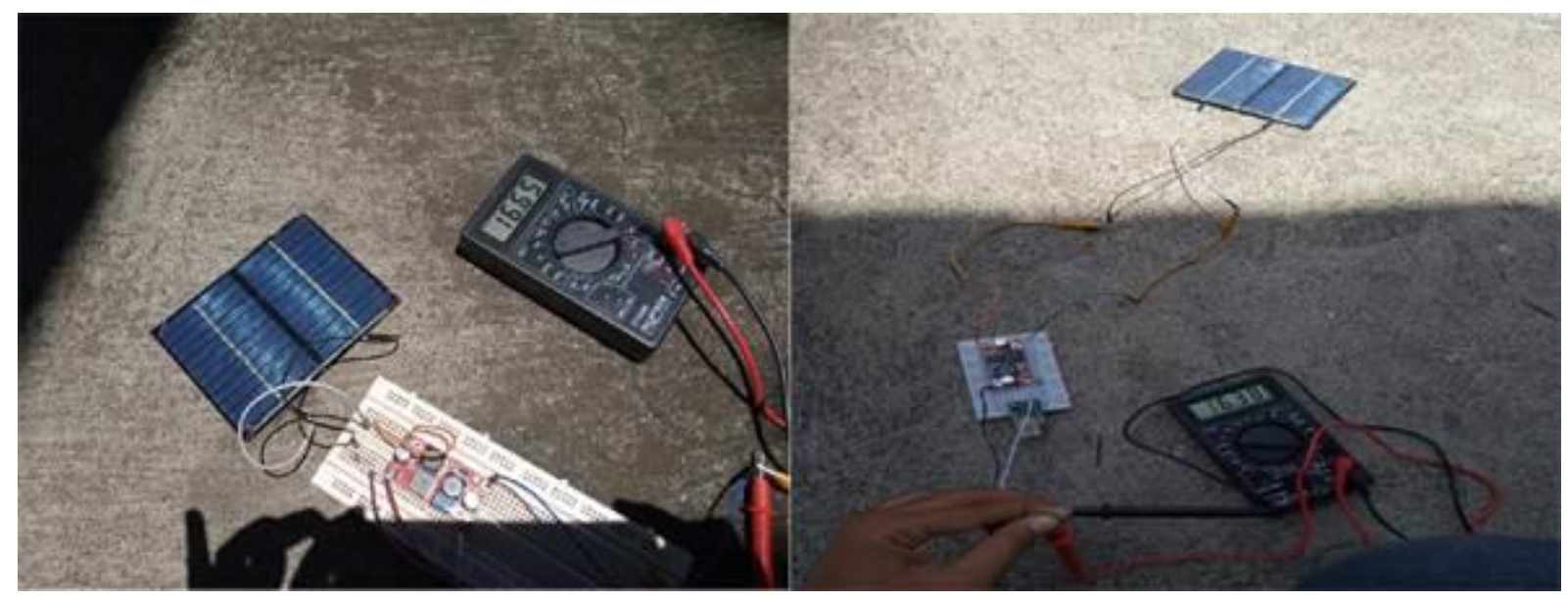

Gambar 8. Pengujian Intensitas Cahaya Matahari yang diterima Panel Surya

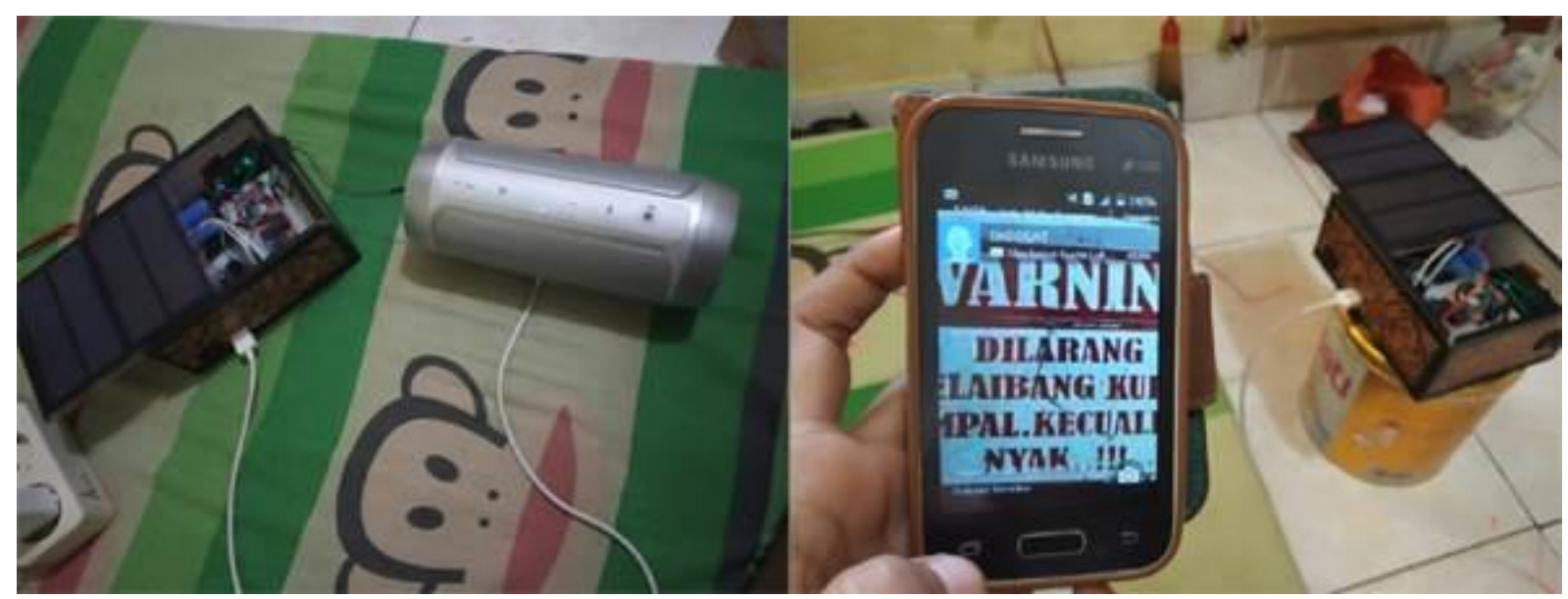

Gambar 9. Pengujian Waktu Pengisian Baterai Telepon Seluler dengan Beban dan Kapasitas Beda 
Berikut ini merupakan tabel hasil pengukuran melalui pengujian tahap pertama yang telah dilaksanakan sebagai berikut:

Tabel 1. Hasil Pengisian Daya Baterai Hari ke-1 dengan Kondisi Cuaca Cerah Berawan

\begin{tabular}{cccccccc}
\hline No & $\begin{array}{c}\text { Waktu } \\
\text { (Wita) }\end{array}$ & $\begin{array}{c}\text { Intensitas } \\
\text { Cahaya } \\
\text { (Cd/Candela) }\end{array}$ & $\begin{array}{c}\text { Tegangan } \\
\text { Panel } \\
\text { Surya } \\
\text { (Volt) }\end{array}$ & $\begin{array}{c}\text { Arus } \\
(\mathrm{A})\end{array}$ & $\begin{array}{c}\text { Tegangan } \\
\text { Output } \\
\text { Pengisi } \\
\text { Daya (V) }\end{array}$ & Kondisi & $\begin{array}{c}\text { Level Baterai } \\
\text { (strip) }\end{array}$ \\
\hline 1 & 06.30 & 6.490 & 3.15 & 0 & 2.96 & Tidak mengisi & 1 \\
2 & 07.00 & 28.000 & 3.90 & 0 & 2.96 & Tidak mengisi & 1 \\
3 & 08.00 & 39.470 & 5.33 & 0.04 & 2.98 & Mengisi & 1 \\
4 & 09.00 & 70.470 & 5.40 & 0.05 & 3.11 & Mengisi & 2 \\
5 & 10.00 & 77.470 & 5.44 & 0.06 & 3.15 & Mengisi & 2 \\
6 & 11.00 & 85.470 & 5.49 & 0.06 & 3.18 & Mengisi & 2 \\
7 & 12.00 & 92.000 & 5.51 & 0.06 & 3.20 & Mengisi & 3 \\
8 & 13.00 & 87.000 & 5.47 & 0.06 & 3.22 & Mengisi & 3 \\
9 & 14.00 & 82.470 & 5.44 & 0.06 & 3.25 & Mengisi & 3 \\
10 & 15.00 & 64.000 & 5.30 & 0.05 & 3.28 & Mengisi & 3 \\
11 & 16.00 & 40.490 & 4.88 & 0.02 & 3.30 & Mengisi & 3 \\
12 & 17.00 & 35.000 & 4.50 & 0.01 & 3.31 & Mengisi & 3 \\
13 & 18.00 & 28.270 & 3.20 & 0 & 3.31 & Tidak mengisi & 3 \\
\hline
\end{tabular}

Tabel 2. Hasil Pengisian Daya Baterai Hari ke-2 dengan Kondisi Cuaca Cerah Berawan

\begin{tabular}{cccccccc}
\hline No & $\begin{array}{c}\text { Waktu } \\
\text { (Wita) }\end{array}$ & $\begin{array}{c}\text { Intensitas } \\
\text { Cahaya } \\
\text { (Cd/Candela) }\end{array}$ & $\begin{array}{c}\text { Tegangan } \\
\text { Panel } \\
\text { Surya } \\
\text { Volt) }\end{array}$ & $\begin{array}{c}\text { Arus } \\
(\mathrm{A})\end{array}$ & $\begin{array}{c}\text { Tegangan } \\
\text { Output } \\
\text { Pengisi } \\
\text { Daya (V) }\end{array}$ & Kondisi & $\begin{array}{c}\text { Level Baterai } \\
\text { (strip) }\end{array}$ \\
\hline 1 & 06.30 & 7.490 & 4.91 & 0 & 2.94 & Tidak mengisi & 1 \\
2 & 07.00 & 21.700 & 3.32 & 0 & 2.94 & Tidak mengisi & 1 \\
3 & 08.00 & 32.000 & 5.22 & 0.01 & 2.97 & Mengisi & 1 \\
4 & 09.00 & 53.000 & 5.46 & 0.04 & 3.0 & Mengisi & 2 \\
5 & 10.00 & 73.000 & 5.49 & 0.06 & 3.09 & Mengisi & 2 \\
6 & 11.00 & 92.000 & 5.51 & 0.06 & 3.12 & Mengisi & 2 \\
7 & 12.00 & 95.000 & 5.37 & 0.06 & 3.14 & Mengisi & 2 \\
8 & 13.00 & 93.000 & 5.40 & 0.06 & 3.20 & Mengisi & 3 \\
9 & 14.00 & 84.000 & 5.33 & 0.06 & 3.27 & Mengisi & 3 \\
10 & 15.00 & 66.000 & 5.27 & 0.05 & 3.30 & Mengisi & 3 \\
11 & 16.00 & 31.200 & 4.96 & 0.02 & 3.31 & Mengisi & 3 \\
12 & 17.00 & 29.400 & 4.56 & 0.01 & 3.32 & Mengisi & 3 \\
13 & 18.00 & 20.000 & 4.00 & 0 & 3.32 & Tidak mengisi & 3 \\
\hline
\end{tabular}

Tabel 3. Hasil Pengisian Daya Baterai Hari ke-3 dengan Kondisi Cuaca Sedikit Mendung

\begin{tabular}{cccccccc}
\hline No & $\begin{array}{c}\text { Waktu } \\
\text { (Wita) }\end{array}$ & $\begin{array}{c}\text { Intensitas } \\
\text { Cahaya } \\
\text { (Cd/Candela) }\end{array}$ & $\begin{array}{c}\text { Tegangan } \\
\text { Panel } \\
\text { Surya } \\
\text { (Volt) }\end{array}$ & $\begin{array}{c}\text { Arus } \\
(\mathrm{A})\end{array}$ & $\begin{array}{c}\text { Tegangan } \\
\text { Output } \\
\text { Pengisi } \\
\text { Daya (V) }\end{array}$ & Kondisi & $\begin{array}{c}\text { Level Baterai } \\
\text { (strip) }\end{array}$ \\
\hline 1 & 06.30 & 6.390 & 3.15 & 0 & 2.96 & Tidak mengisi & 1 \\
2 & 07.00 & 26.470 & 3.90 & 0 & 2.96 & Tidak mengisi & 1
\end{tabular}




\begin{tabular}{cccccccc}
3 & 08.00 & 42.300 & 5.33 & 0.04 & 2.98 & Mengisi & 1 \\
4 & 09.00 & 68.100 & 5.40 & 0.05 & 3.00 & Mengisi & 2 \\
5 & 10.00 & 6.230 & 5.44 & 0.06 & 3.21 & Mengisi & 3 \\
6 & 11.00 & 8.450 & 5.49 & 0.06 & 3.24 & Mengisi & 3 \\
7 & 12.00 & 34.510 & 5.08 & 0.06 & 3.27 & Mengisi & 3 \\
8 & 13.00 & 29.000 & 5.47 & 0.06 & 3.29 & Mengisi & 3 \\
9 & 14.00 & 33 & 5.44 & 0.06 & 3.30 & Mengisi & 3 \\
10 & 15.00 & 75.840 & 5.30 & 0.05 & 3.31 & Mengisi & 3 \\
11 & 16.00 & 30.940 & 4.88 & 0.02 & 3.32 & Mengisi & 3 \\
12 & 17.00 & 27.470 & 4.50 & 0.01 & 3.33 & Mengisi & 3 \\
13 & 18.00 & 19.000 & 3.20 & 0 & 3.33 & Tidak mengisi & 3 \\
\hline
\end{tabular}

Data yang diperoleh dari hasil pengujian tahap pertama menjelaskan bahwa intensitas cahaya matahari sangat mempengaruhi output tegangan dari panel surya, sehingga semakin besar intensitas cahaya matahari maka semakin besar tegangan yang dihasilkan panel surya, tetapi tidak mempengaruhi besar arus pada panel surya itu sendiri. Intensitas cahaya matahari terbesar didapatkan pada pukul 12.00 Wita, dengan rata-rata intensitas cahaya sebesar 63.000 Candela (Cd).

Berikut ini merupakan tabel hasil pengukuran melalui pengujian tahap kedua yang telah dilaksanakan sebagai berikut:

Tabel 4. Tabel Pengisian Baterai tipe Li-ion 4.81Wh

\begin{tabular}{ccccc}
\hline $\begin{array}{c}\text { Waktu } \\
\text { (menit) }\end{array}$ & $\begin{array}{c}\text { Persentase Level Baterai } \\
\text { Telepon Seluler } \\
(\%)\end{array}$ & $\begin{array}{c}\text { Tegangan Output } \\
(\mathrm{V})\end{array}$ & $\begin{array}{c}\text { Arus } \\
(\mathrm{A})\end{array}$ & $\begin{array}{c}\text { Level Baterai } \\
(\text { strip) }\end{array}$ \\
\hline Awal & 38 & 4.44 & 0.11 & 5 \\
10 & 38 & 4.44 & 0.11 & 5 \\
20 & 39 & 4.44 & 0.10 & 5 \\
30 & 39 & 4.44 & 0.10 & 4 \\
40 & 39 & 4.43 & 0.10 & 4 \\
50 & 40 & 4.43 & 0.10 & 4 \\
60 & 40 & 4.44 & 0.09 & 4 \\
70 & 40 & 4.43 & 0.09 & 4 \\
80 & 41 & 4.43 & 0.07 & 4 \\
90 & 41 & 4.43 & 0.07 & 3 \\
100 & 41 & 4.40 & 0.06 & 3 \\
110 & 42 & 4.40 & 0.06 & 3 \\
120 & 42 & 4.40 & 0.05 & 3 \\
130 & 42 & 4.40 & 0.05 & 3 \\
140 & 43 & 4.35 & 0.05 & 3 \\
150 & 43 & 4.35 & 0.05 & 2 \\
160 & 43 & 4.35 & 0.04 & 2 \\
170 & 43 & 4.35 & 0.04 & 2 \\
180 & 43 & 4.30 & 0.04 & 2 \\
190 & 43 & 4.30 & 0.04 & 2 \\
200 & 43 & 4.30 & 0.04 & 2 \\
210 & 43 & 4.30 & 0.04 & 1 \\
220 & 43 & 4.30 & 0.04 & 0.04 \\
230 & 43 & 4.30 & 0.04 & 2 \\
240 & 43 & 4.30 & & 2 \\
& & & & 3 \\
\hline
\end{tabular}


Tabel 5. Tabel Pengisian Baterai tipe Li-Po 3000mAh

\begin{tabular}{ccccc}
\hline $\begin{array}{c}\text { Waktu } \\
\text { (menit) }\end{array}$ & $\begin{array}{c}\text { Persentase Level Baterai } \\
\text { Telepon Seluler } \\
(\%)\end{array}$ & $\begin{array}{c}\text { Tegangan Output } \\
(\mathrm{V})\end{array}$ & $\begin{array}{c}\text { Arus } \\
(\mathrm{A})\end{array}$ & $\begin{array}{c}\text { Level Baterai } \\
(\text { strip) }\end{array}$ \\
\hline Awal & 74 & 4.45 & 0.09 & 4 \\
10 & 74 & 4.45 & 0.09 & 4 \\
20 & 74 & 4.45 & 0.09 & 4 \\
30 & 74 & 4.44 & 0.09 & 4 \\
40 & 74 & 4.44 & 0.08 & 4 \\
50 & 75 & 4.44 & 0.08 & 4 \\
60 & 75 & 4.40 & 0.08 & 3 \\
70 & 75 & 4.40 & 0.08 & 3 \\
80 & 75 & 4.40 & 0.06 & 3 \\
90 & 75 & 4.40 & 0.06 & 3 \\
100 & 75 & 4.30 & 0.06 & 3 \\
110 & 76 & 4.30 & 0.05 & 3 \\
120 & 76 & 4.30 & 0.04 & 2 \\
130 & 76 & 4.30 & 0.04 & 2 \\
140 & 76 & 4.30 & 0.04 & 2 \\
150 & 76 & 4.30 & 0.04 & 2 \\
160 & 76 & 4.30 & 0.04 & 2 \\
170 & 77 & 4.30 & 0.04 & 2 \\
180 & 77 & 4.30 & 0.02 & 1 \\
190 & 77 & 4.30 & 0.01 & 1 \\
\hline
\end{tabular}

Tabel 6. Tabel Pengisian Baterai Speaker Portabel tipe Li-Po 6000mAh

\begin{tabular}{ccccc}
\hline $\begin{array}{c}\text { Waktu } \\
\text { (menit) }\end{array}$ & $\begin{array}{c}\text { Persentase Level Baterai } \\
\text { Telepon Seluler } \\
(\%)\end{array}$ & $\begin{array}{c}\text { Tegangan Output } \\
(\mathrm{V})\end{array}$ & $\begin{array}{c}\text { Arus } \\
(\mathrm{A})\end{array}$ & $\begin{array}{c}\text { Level Baterai } \\
(\text { strip) }\end{array}$ \\
\hline Awal & 20 & 4.40 & 0.09 & 4 \\
10 & 30 & 4.40 & 0.08 & 4 \\
20 & 40 & 4.40 & 0.08 & 4 \\
30 & 50 & 4.40 & 0.08 & 4 \\
40 & 60 & 4.38 & 0.08 & 4 \\
50 & 70 & 4.38 & 0.08 & 4 \\
60 & 80 & 4.38 & 0.08 & 3 \\
70 & 90 & 4.38 & 0.08 & 3 \\
80 & 100 & 4.38 & 0.08 & 3 \\
\hline
\end{tabular}

Data yang diperoleh dari hasil pengujian tahap kedua menjelaskan bahwa waktu pengisian baterai telepon seluler memerlukan waktu 2 jam 10 menit, dan kapasitas pengisi daya baterai berada pada level strip 1 yang mampu mengisi hingga $29 \%$.

\section{SIMPULAN DAN SARAN}

Berdasarkan perancangan, pembuatan, pengujian serta analisis data yang telah dilakukan dalam penelitian ini, maka dapat disimpulkan bahwa seluruh rangkaian panel surya, buck boost converter, rangkaian modul pengisi daya, baterai dan rangkaian modul USB sudah mampu bekerja sesuai dengan yang diharapkan. 
Intensitas cahaya matahari sangat mempengaruhi output tegangan panel surya, sehingga semakin besar intensitas cahaya matahari yang diterima maka semakin besar tegangan yang dihasilkan oleh panel surya, tetapi tidak mempengaruhi besar arus pada panel surya tersebut. Intensitas cahaya matahari terbesar didapatkan pada pukul 12.00 wita, dengan rata-rata intensitas cahaya matahari sebesar 63.000 Candela yang menghasilkan tegangan sebesar \pm 5.3 Volt dan arus sebesar \pm 0.06 Ampere. Hasil pengujian waktu pengisian baterai telepon seluler, memerlukan waktu 2 jam 10 menit dan kapasitas pengisi daya baterai sudah berada pada level strip 1 yang mampu mengisi hingga $29 \%$.

Untuk menyempurnakan dan lebih mengembangkan alat pengisi daya telepon seluler portabel ini maka dikemukakan saran - saran sebagai berikut:

Pengisi daya telepon seluler portabel ini masih bersifat alternatif dan dalam situasi darurat, efektif digunakan dalam keadaan tidak ada sumber listrik baik dari PLN atau sumber dari pembangkit lain yang lebih besar dalam penyediaan tenaga listrik. Pengisi daya telepon seluler portabel ini juga belum mampu memutus secara otomatis pada baterai pada saat kondisi baterai sudah penuh. Untuk penelitian selanjutnya, diharapkan dapat menggunakan panel surya yang dimensinya lebih kecil, dan mampu mengisi daya lebih cepat di atas $29 \%$.

\section{DAFTAR PUSTAKA}

[1] Afifah, Hilyati. 2016. "Perancangan Alat Otomatis Penyemprot Tanaman Hama Padi Menggunakan Sensor Pir dengan Sumber Baterai". ( unej.ac.id ) Tersedia pada http://repository.unej.ac.id/handle/123456789/73481

[2] Andi Prasetyo. 2018. "Pengertian Resistor, Jenis-jenis Resitor dan Fungsi resistor". (kompasiana.com). Tersedia pada https://www.kompasiana.com/spampam/5b86b6e46ddcae2040310973/resistor-pengertianresistor-jenis-jenis-resistor-da-fungsi-resistor?page $=2$

[3] Dickshon Kho. 2019. "Fungsi Dioda dan Cara Mengukurnya". (teknikelektronika.com). Tersedia pada https://teknikelektronika.com/fungsi-dioda-cara-mengukur-dioda/

[4] Galih Raditya. 2017. "Sejarah Sel Surya dan Perkembangannya Hingga Hari Ini". (Janaloka.com). Tersedia pada https://janaloka.com/sejarah-sel-surya/. (9 Agustus 2017).

[5] Gede Bayu Mahendra. 2012. Hand Charger Portable menggunakan Motor DC. Tugas Akhir 2012. Jurusan D3 Teknik Elektronika, Undiksha Singaraja.

[6] I Gede Nurhayata. 2017. "Pengembangan Tegangan Panel Surya Portable Berbasis Close Loop Boost Converter". (eproceeding.undiksha.ac.id). Tersedia pada

http://eproceeding.undiksha.ac.id/index.php/semnasvoktek/article/view/703

[7] I W Sutaya, K U Ariawan. 2016. "Solar Tracker Cerdas dan Murah Berbasis Mikrokontroler 8 bit ATMega 8535". (ejournal.undiksha.ac.id). Tersedia pada https://ejournal.undiksha.ac.id/index.php/JST/article/view/8272

[8] Komang Deli Sujaya. 2017. "Reparasi Power Supply Model Switching Mode Power Supply di Lab Elektro". Laporan PKL 2017. Jurusan D3 Teknik Elektronika, Undiksha Singaraja.

[9] Kurnia Rivaldo, 2019. "Buck Boost Converter". (academia.edu). Tersedia pada https://www.academia.edu/33004672/BUCK-BOOST_CONVERTER.

[10] Putu Yoga Purnam Sidhi. 2017. "Pembuatan Rangkaian Driver Motor untuk Penggerak Modul Surya (Solar Tracker)". Tugas Akhir 2017. Jurusan D3 Teknik Elektro, Politeknik Negeri Kupang.

[11] Sudrajat Alfatih. 2013. "Pengertian Battery Charger". (Simpai Bada' Senja.com). Tersedia pada http://asm-sudrajatalfatih.blogspot.com/2013/09/pengertian-battery-charger.html 